\title{
Serum Neutrophil Gelatinase-Associated Lipocalin as a Biomarker for Early Renal Dysfunction in Adult Egyptian Patients with $\beta$-Thalassemia Major
}

\author{
NELLY D. EL-SHALL, M.D.; AMAL S. EL-BENDARY, M.D.; HANAA I. OKDA, M.D. and \\ KAREEM A. EL-ASHRY, M.Sc.
}

The Department of Internal Medicine, Faculty of Medicine, Tanta University

\begin{abstract}
Background: Renal dysfunction in thalassemia may occur before the occurrence of any symptoms, Induction of NGAL after kidney injury precedes the elevation of classical markers for kidney damage, which made it a promising marker for renal dysfunction in $\beta$-thalassemia, major.
\end{abstract}

Aim of the Work: To assess value of serum NGAL in patients with $\beta$-thalassemia major as an early marker of renal impairment.

Patients and Methods: The present study enrolled 70 subjects and they were classified into two main groups:

- Group (I): 20 apparently healthy normal volunteers.

- Group (II): 50 multi-transfused $\beta$-thalassemia major patients.

Which subdivided according to chelation therapy into two subgroups:

- Subgroup (I): On regular iron chelation therapy.

- Subgroup (II): Without chelation therapy.

Results: In our study serum NGAL was significantly elevated in group II compared to control group. Also in our study, we found a direct correlation between NGAL and urea, creatinine, eGFR, ferritin, transferrin saturation while there was inverse correlation between NGAL and hemoglobin, $\beta 2$ microglobulin.

Conclusion: NGAL could be considered as early predictor of renal dysfunction in thalassemia.

Key Words: Thalassemia major - Renal dysfunction - NGAL.

\section{Introduction}

NEUTROPHIL Gelatinase-Associated Lipocalin [NGAL] is a very early and sensitive biomarker of kidney injury. The origin and time course of NGAL were assessed in several experimental and clinically relevant renal diseases. Neutrophil Gelatinase-Associated Lipocalin [NGAL] is a differ-

Correspondence to: Dr. Nelly D. El-Shall, The Department of Internal Medicine, Faculty of Medicine, Tanta University entiation inducer for epithelia in embryonic kidney, whose expression is dramatically increased in kidney injury [1] . NGAL may eventually have prognostic value in predicting not only acute, but also chronic worsening in renal function in patients already affected by chronic nephropathies. For all these reasons, it can be expected that the future hold the promise of new interesting applications of NGAL measurement in clinical nephrology and beyond [2].

Patients with Beta-thalassemia have partial or complete lack of synthesis of beta-chain of hemoglobin, the remaining excess of $\alpha$-chain is unstable, and they eventually precipitate and disintegrate, causing damage to the red blood cell membrane. The affected RBCs are prematurely hemolyzed in the bone marrow and spleen, resulting in increased RBCs turnover, ineffective erythropoiesis and severe anemia. Which can be corrected only by regular blood transfusions. One of the major consequences of this genetic disorder is iron overload due to ineffective erythropoiesis and premature hemolysis in the plasma and in major organs such as heart, liver and endocrine glands [3]. Little attention has been paid to the possible involvement of the kidney in patients with $\beta$-thalassemia. However, recent studies outlined the presence of different tubular and glomerular abnormalities [4]. Renal dysfunction may occur in $\beta$-thalassemia major patients showing no clinical symptoms before the manifestations of any other complications that may occur by persistent hypoxia, anemia, and severe iron overload and over chelation [5]. It is crucial to examine how to assess renal function accurately to allow early diagnosis of kidney disease. In the past, the serum creatinine was used for its convenience as a measure, as it is easily measured from 
a blood sample. However, this correlates poorly with the gold standard measurement of kidney function because $50 \%$ of people, despite a normal measured serum creatinine on a routine blood test, have evidence of impaired kidney function [6]. So there is an urgent need for early predictive biomarkers of renal impairment in Beta-thalassemia major as early intervention can significantly improve the prognosis [7].

\section{Patients and Methods}

This is a cross-sectional study carried out at Tanta University Hospital and Tanta Health Insurance Hospital starting from July 2016 to January 2017.

The study included two groups:

First group [control group]:It included 20 apparently healthy volunteers as a control group (10 males and 10 females).with mean age 33.26 \pm 5.43 years.

Second group [patients group]: It included 50 multi-transfused $\beta$-thalassemia major patients (27 males and 23 females). Their mean age was $30 \pm 7.2$ years.

Where they subdivided according to chelation therapy into to subgroups:

Subgroup (I): On regular iron chelation therapy. This group included 31 patients (17 males and 14 females). Their mean age was $29.03 \pm 5.95$ years.

Subgroup (II): without chelation therapy. This group included 19 patients ( 10 males and 9 females). Their mean age was $30.36 \pm 9$ years.

\section{The inclusion criteria:}

1- Patient age $>18$ of both sexes.

2- Patients with $\beta$-thalathmia major as evidenced by the following criteria at the time of initial diagnosis (age at presentation was less than 2 years with a mean hemoglobin level of $6-7 \mathrm{~g} / \mathrm{dl}$, $\mathrm{HbF}>50 \%$, and $\mathrm{HbA} 2<4 \%$ ).

\section{The exclusion criteria:}

1- Patients with other hemoglobinopathies.

2- Patients with other hemolytic anemia.

3- Patients with systemic illness (heart failure, hepatic diseases, or diabetes mellitus).

4- Patients with clinical or laboratory evidence of other causes of renal diseases.

\section{Ethical considerations:}

Informed written consent obtained from all patients included full explanation of the benefits and risks of the study.

Methods:

All patients in the study were subjected to:

1- Full history taking.

2- Complete clinical examination.

3- Imaging including: Abdominal ultrasound.

4- Laboratory tests including:

A- Routine investigations:

- Complete blood picture.

- Serum Ferritin (ng/dl).

- Transferrin saturation (\%).

- Random blood sugar (mg/dl).

- $C$ reactive protein $(\mathrm{mg} / \mathrm{dl})$.

- Urine analysis.

- Blood urea (mg/dl) and serum creatinine (mg/dl).

- Estimated glomerular filtration rate by Çockcroft-Gault Equation $\left(\mathrm{ml} / \mathrm{min} / 1.73 \mathrm{~m}^{2}\right)$.

B- Special laboratory tests:

- Serum Beta-2 microglobulin (mg/l).

- ELISA technique for estimation NGAL in serum.

Statistical analysis:

Statistical presentation and analysis of the present study was conducted using the mean, standard deviation and chi-square test by SPSS V.20.

\section{Results}

\section{1-Demographic data:}

Study population were compared according to age (Table 1 ) with no statistically significant difference as $p$-value was $0.086(>0.05)$.

The two subgroups were compared according to age (Table 2) with no statistically significant difference as $p$-value was $0.531(>0.05)$.

2- NGAL (ng/ml) mean values were 22.27 with SD 7.1 in group (II) and 9.14 with SD 3.02 ingroup (I). There was a highly significance difference as $(p<0.0001)$ as presented in (Table 3$)$.

3- NGAL (ng/ml) mean values were 18.90 with SD 5.27 in subgroup (I) and 27.75 with SD 6.30 in subgroup (II) in patient group. There was a highly significance difference as $(p<0.0001)$ as presented in (Table 4). 
Table (1): Age means values of the two groups.

\begin{tabular}{llll}
\hline & $\begin{array}{c}\text { Patient group } \\
(\mathrm{n}=50)\end{array}$ & $\begin{array}{c}\text { Control group } \\
(\mathrm{n}=20)\end{array}$ \\
\hline Rang & $21-54$ & & $20-45$ \\
Mean $\pm \mathrm{SD}$ & $29.54 \pm 7.21$ & & $32.7 \pm 5.87$ \\
$t$-value & & 1.74 & \\
$p$-value & & 0.086 & \\
\hline
\end{tabular}

Table (2): Age means values of patient sub groups.

\begin{tabular}{|c|c|c|}
\hline & Sub group $_{(\mathrm{n}=31)}(1)$ & $\underset{(n=19)}{\text { Sub group }}(2)$ \\
\hline Rang & $21-42$ & $21-54$ \\
\hline Mean \pm SD & $29.03 \pm 5.95$ & $30.36 \pm 9$ \\
\hline$t$-value & \multicolumn{2}{|c|}{0.630} \\
\hline$p$-value & & \\
\hline
\end{tabular}

Table (3): NGAL mean values of the two groups.

\begin{tabular}{|c|c|c|c|}
\hline & $\begin{array}{l}\text { Patient group } \\
\quad(\mathrm{n}=50)\end{array}$ & & $\begin{array}{c}\text { Control group } \\
(\mathrm{n}=20)\end{array}$ \\
\hline Rang & $9.40-39$ & & $3.4-14$ \\
\hline Mean \pm SD & $22.27 \pm 7.1$ & & $9.14 \pm 3.02$ \\
\hline$t$-value & & 7.959 & \\
\hline$p$-value & & $<0.0001$ & \\
\hline
\end{tabular}

Table (4): NGAL mean values of the two sub groups.

\begin{tabular}{|c|c|c|}
\hline & $\underset{(\mathrm{n}=31)}{\text { Sub group }}(1)$ & $\begin{array}{c}\text { Sub group } \\
(\mathrm{n}=19)\end{array}$ \\
\hline Rang & $9.4-29.1$ & $12.6-39$ \\
\hline Mean \pm SD & $18.90 \pm 5.27$ & $27.75 \pm 6.30$ \\
\hline$t$-value & \multirow{2}{*}{\multicolumn{2}{|c|}{$\begin{array}{c}5.30 \\
<0.0001\end{array}$}} \\
\hline$p$-value & & \\
\hline
\end{tabular}

\section{Discussion}

The survival of the patients with $\beta$-thalassemia major has improved recently due to both effective oral chelating agents and novel imaging modalities pointing visceral iron overload earlier. Extending patients survival leads to many organ dysfunctions [8]. Regarding renal injury, several factors might play role in patients with thalassemia. Chronic hypoxia, ongoing hemolysis, iron overload owing to transfusions and possible nephrotoxicity of chelators are well-known reasons of the deterioration in renal functions [9].

The principal finding of the present study was that that there was a high significant difference between the two groups, also there was a significant difference between the two sub groups regarding the serum neutrophil gelatinase-associated lipocalin levels.

Ioannis P et al., (2009); [10] reported in a Greek study included 150 patients that NGAL levels were significantly increased in the thalassemia patients studied compared to normal controls.

Similar findings were reported by Mehryar $\mathrm{H}$ et al., (2008); [11] who reported that adult betathalassemia patients upregulated NGAL expression compared with the normal sample and explained it by upregulation that play an important role in decreasing iron in thalassemia patients.

Gulcihan O et al., (2014); [12] in agreement with us also reported that the NGAL is higher in patients group compared to control group.

According to Aikaterini P et al., (2014); [13] many reasons are contemplated for elevated NGAL at thalassemia patients including anemia/hypoxia, renal damage, and iron homeostatic disturbances.

Alok H (2017); [14] submitted a research paper at SPADS conference discussing NGAL as indicator of renal injury in Indian beta Thalassemia disease children. He found a positive significant correlation between duration of chelation and serum NGAL.

\section{Conclusion:}

- Renal dysfunction in thalassemia may occur before the occurrence of any symptoms or complications and may be explained by anemia/ hypoxia, repeated blood transfusion, iron overload and by toxicity of chelators.

- NGAL could be considered as early predictor of renal tubular and glomerular dysfunction in thalassemia.

\section{References}

1- DEVARAJAN P.: Neutrophil gelatinase-associated lipocalin (NGAL): A new marker of kidney disease; Scand. J. Clin. Lab. Invest. Suppl., 241: 89-94, 2008.

2- DAVIDE B., GIUSEPPE S., ANTONIO L., et al.: Neutrophil Gelatinase-Associated Lipocalin (NGAL) as a Marker of Kidney Damage; Am. J. Kidney Dis., 52 (3): 595-605, 2008.

3- JEAN A., JEAN B., MICHAEL D., et al.: Ineffective Erythropoiesis in $\beta$-Thalassemia; Scientific World J., 4 (1): 394-95, 2013.

4- HARB A., SALIBA A. and TAHER A.: Non-transfusion dependent thalassemia: Translating evidence to guidelines; Thalassemia Reports, 4 (3): 560-66, 2014.

5- KOLIAKOS G., PAPACHRISTOU F., KOUSSI A., et al.: Urine biochemical markers of early renal dysfunction are associated with iron overload in $\beta$-thalassemia: International Journal of Laboratory Hematology, 25 (2): 105 9, 2003.

6- HEWITT S., DEAR J. and STAR R.: Discovery of protein biomarkers for renal diseases; Journal of the American Society of Nephrology, 15 (7): 1677-89, 2004. 
7- COHEN A., GALANELLO R., PENNELL D., et al.: Thalassemia; ASH Education Program Book, 1: 14-34, 2004.

8- RUND D. and RACHMILEWITZ E.: ( 3 -Thalassemia; New England Journal of Medicine, 353 (11): 1135-46, 2005.

9- GOKCE M., KUP H., TUGCU D., et al.: Insidious Renal Damage in Patients with Thalassemia Major: Is it More Serious than Appreciated; Journal of Hematology \& Thromboembolic Diseases, 11 (2): 133-8, 2014.

10- IOANNIS P., ELIZABETH T., AIKATERINI P., et al.: Plasma neutrophil gelatinase-associated lipocalin levels are markedly increased in patients with non-transfusiondependent thalassemia: Lack of association with markers of erythropoiesis, iron metabolism and renal function; Clinical Biochemistry, 47 (12): 1060-64, 2014.

11- MEHRYAR H., RAHELEH H., AREZOO O., et al.:
Upregulation of neutrophil gelatinase-associated lipocalin, NGAL/Lcn2, in (3-thalassemia patients; Archives of Medical Research, 39 (4): 402-7, 2008.

12- GULCIHAN O., ÖZGÜR C., ERKIN S., et al.: Renal Dysfunction in Pediatric Thalassemia Major Patients and Evaluation of Urine NGAL Levels in Thalassemia, 124 (21): 40-9, 2014.

13- AIKATERINI P., ELIZABETH T., ALEXANDRA M., et al.: Plasma neutrophil gelatinase-associated lipocalin levels are markedly increased in patients with nontransfusion-dependent thalassemia: Lack of association with markers of erythropoiesis: Iron metabolism and renal function; Clinical Biochemistry, 47: 1060-64, 2014.

14- ALOK H.: Neutrophil gelatinase-associated lipocalin (NGAL) as indicator of renal injury in Indian beta Thalassemia disease children; Special Pathogens Review Journal, 82 (12): 1082-83, 2017.

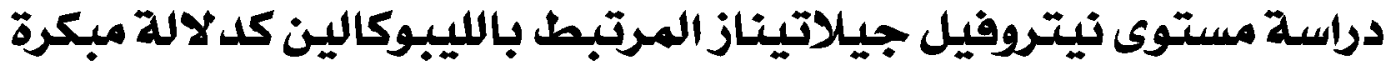 للقصور الكلوى في مرضيى آنيميا البحر المتئوسط باليوكالين بيتا}

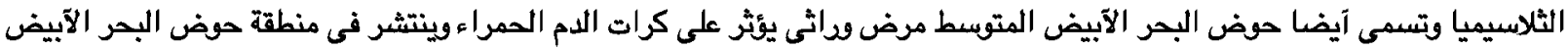

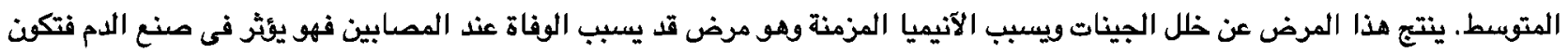

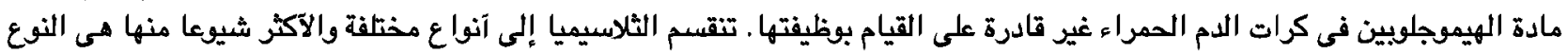

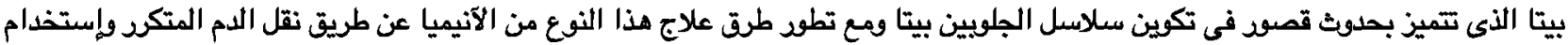

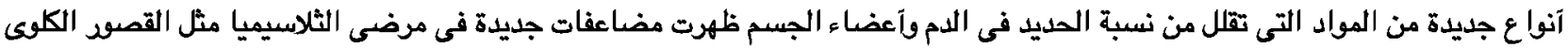
وظهرت الحاجة إلى دلالات مبكرة للقصود الكلىى لعلاجه مبكرا قبل آن يتطود إلى فشل كلمى وتثل فرص الته علاجه.

آجرى هذا البحث على سبعين شخصا من البالغين وهم مقسمين كالتالى: • المجموعة الآولى: عشرن شخصا آصحاء كمجموعة ضابطة.

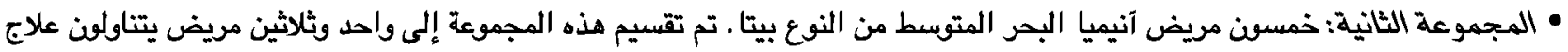

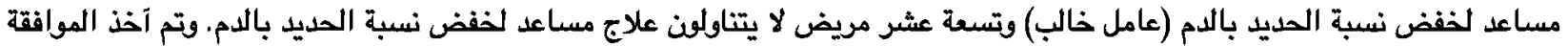
المسبقة من جميع المشاركين.

آجريت الدراسة على السن أكثر من \1 عام من الجنسين فى مرضى آنيميا البحر المتوسط من النوع بيتا ويتم تشخيصها بالتاريخ المرضى والفحص الإكلينيكى والمعملى. وقد آظهرت النتائج آنه: • تد يحدث خلل كلوى فى الثُاسيميا قبل حدوث آى آعراض آى مضاعفات ويمكن تفسيره بفقر الدم ونقل الدم المتكرر والترسيب الزائد اللصدي،

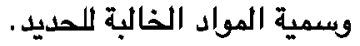

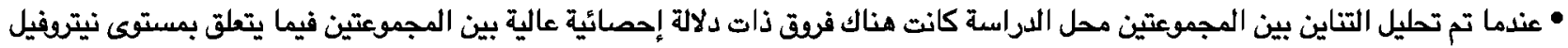

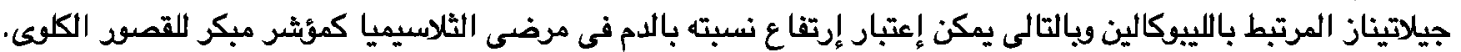

